\title{
Quality at stake: Travails of the multigrade teachers in the Division of Southern Leyte
}

\author{
Magpatoc, Argie G. $\bowtie$ \\ San Roque Elementary School, Philippines (aremheck@gmail.com)
}

Received: 23 August 2021

Revised: 20 September 2021

Available Online: 26 September 2021

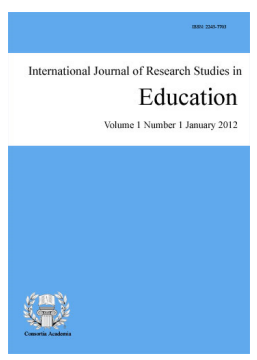

Accepted: 26 September 2021

ISSN: $2243-7703$ Online ISSN: 2243-7711

OPEN ACCESS

\section{Abstract}

The study is all about the travails of the Multigrade Teachers in the Division of Southern Leyte with which the quality education may be at stake. The phenomenological research design was utilized to explore, narrate and document the experiences of teachers in the three Cs: content, connection and character. With the travails narrated by the teachers, the study focused on how they effectively delivered the content; how connection was maintained with the learners in different grade levels in one classroom; and how the teacher ethically and professionally conducted the self-inside and outside the classroom to uphold quality multigrade education. The data were gathered from 31 multigrade teachers. The findings of the study revealed that the multigrade teachers gave their best effort to deliver quality multigrade education; the teachers could hardly have enough time to prepare appropriate instructional materials and learning activities to effectively maintain connection with the learners in different grade levels; and the teachers ethically and professionally conducted their character as they instrument for strong foundations of quality education. In conclusion, the quality of multigrade education depends on the teachers' professional skills and attitude.

Keywords: quality education, multigrade education, travails, content, connection, character 


\section{Quality at stake: Travails of the multigrade teachers in the Division of Southern Leyte}

\section{Introduction}

Quality education is having basic skills, knowledge and attitudes achieved and retained by the learner so it can be used effectively in their daily lives. According to ASCD (2018) on its blog quality education focuses on the whole child: a successful child whose achievement is measured on the social, emotional, mental, physical, and cognitive development of each student regardless of gender, race, ethnicity, socioeconomic status, or geographical location. It prepares the child for life, not just for testing. The concept of quality education for all includes two dimensions: of how effectively education is achieving its learning objectives, and of how much of the target population is being reached (Boonzaaiier, 2008). In the Philippine educational setting, there is the so called multigrade education in order to address the needs for education of those who are situated in far-flung or very remote areas where schools have problems on low population density, scarcity of classrooms and even teachers.

Multigrade education is where one teacher teaching two, three or more grade levels in a day simultaneously and it appears that effectiveness and the quality education is dependent on the type of teachers' efforts and class management (Enayati et al., 2016). Thus, the effective delivery of multigrade education depends largely on how teacher squarely faces the other different correlates in addition to the mastery of pedagogic approaches. Multigrade teaching has been practiced in the schooling system as accepted by UNESCO as a reliable alternative strategy to single grade teaching. Studies about multigrade education were conducted but only very few or no study yet was made on how multigrade teachers faced the difficulties of delivering quality multigrade education (Kucita et al., 2013). Hence, according to Little (2006) the possible reason is that in most countries teacher education for multigrade education either does not exist at all.

In some countries like Nepal, one teacher may handle more than one grade level together where the classroom may be different or same. In Malaysia, a teacher accommodates two or more levels in one classroom and teaches them together. In Pakistan, three levels or even more are grouped in a classroom setting and a single teacher taught the entire class simultaneously (Nawab, 2011). In France 10\% of French schools hold 3 to 3 multilevels classes in one classroom, with all levels as few as a dozen pupils. Several problems on multigrade teaching had already been reported. Among these problems are teaching methods (Dupriez, Dumay, \& Vause, 2008); poverty which causes absenteeism, nutrition and health deficiency, which affect academic performance and lack of essential instruction, communication and transportation (Seher, 2018). Moreover, lack of essential facilities in particular, textbooks and learning materials; communication and transportation are utmost difficulty of the multigrade teacher on how to sustain connection with the school and the learners for quality education (Kivunja \& Sims, 2015).

In most cases allocating resources for instruction is taken from personal expense of the teacher. According to Beihammer and Kaisa (2015), for effective delivery of instruction, good consideration of a well-planned learning experiences during actual class sessions and course-related activities are expected to be an essential skill of the teacher. Because of high expectations of the school administrators, parents, and other stakeholders, the multigrade teacher has to exert optimum effort to realize the goal of quality education by focusing on instructional results, using variety of teaching strategies, effective classroom management, and intervention strategies like remedial instruction, re-teaching and regrouping to ensure that all students achieve a reasonable level of mastery (Enayati et al., 2016).

In Japanese basic education, the three R's are underlined by the three C's: Connection, Character and Content. The emphasis on students' close human connections, social and ethical development, and learning in depth of the curriculum. This study profoundly differs because the focus of the three C's is the multigrade 
teachers. With the aforementioned common experiences and travails of the multigrade teachers', the study aims to explore, narrate, and document how the multigrade teachers sustained Connection for quality education; effectively deliver Content to two, three or more grade levels in one classroom; and how the teacher professionally Characterized the expectations for quality multigrade education.

\subsection{Objective of the Study}

This study aimed to explore, document and narrate, and give meanings of the teachers' travails in teaching multigrade classes in the Division of Southern Leyte.

\subsection{Significance of the Study}

The result of the study is a development of booklet entitled "The 3C's, Travails of Multigrade Teaching" which is useful for teachers in managing multigrade classes. This material would likewise provide significant contribution towards achieving quality education in the context of multigrade classroom. This handbook featuring the documented travails of the multigrade teachers may boost teachers' self-confidence, self-esteem, ego, enthusiasm and pride that their efforts are not in vain because as multigrade teachers, they are considered as strong foundations of quality education.

\section{Literature review}

\subsection{Multigrade Teaching}

Multigrade Teaching refers to teaching children in a setting in which a single teacher has sole responsibility for two or more grade of students simultaneously (Birch \& Lally, 1995; Haargeaves, 2001). Little (1995) refers it to the teaching in which one teacher instructs pupils of different ages, grades and abilities at the same time. It is referred in various literatures as 'multi-level', 'multiple classes' or 'composite class'. In Sri Lanka, multigrade teaching is an instructional arrangement that demands a situation where school requires that learners from more than one grade are taught together providing learning activities and instructions suited and appropriate for the level of each grade; thus it allows the learners to gain benefit that is equal to their learning experiences (NIE, Sri Lanka, 2013).

Flexible grouping strategies as significant contributions to students' learning in multi-age teaching (Kalaoja \& Cornish, 2006: Hoffman, 2002) seem to be the grouping of the students, the selection of the contents for different groups, and the preparation of activities and teaching materials since (Vithanapathirana, 2006) stated that multigrade teaching is adopted out of necessity (Aryal, 2003) and is not an answer to meeting teachers or learners shortage in the educational systems but is a strategy to improve the quality of education in rural communities. Hence, according to Sibli (2003) many developed countries accept it as an effective strategy to improve the quality of education as a pedagogical choice, and address the need of the learners of sparse rural areas.

Multigrade teachers are most likely to be working in situations involving local communities. General and somewhat more theoretical factors in the pedagogy of education needs a great paradigm shift on educational approaches or educational thinking considering their roles to the pupils, parents, community in multigrade teaching gap and issues relating to quality of education is being bridged by them. Teachers utilize organizational structure in which learners of different grades and ability levels are grouped together, without dividing them or the curriculum into steps labelled by grade designation (Gaustad, 2010). Grant (2010) said that mutigrade teacher vents concerns about multigrade teaching since this environment requires more planning and monitoring than a monograde classroom.

Veenman (1995) as cited by Alrajhri (2015), Nepal countries where $40 \%$ of the teachers felt unprepared for 
multigrade classrooms spend much of their time in learning quality learning materials because they did not choose the position or the assignment as multigrade teachers. For this to happen, teacher preparation must openly address the context-specific needs, diverse as they often are, since it is more on planning, preparation, organization and work, catering for a wider range of abilities and maturity, less time for meeting individual student needs and for remediation, less time for reflection on teaching, lack of relevant professional training, and less satisfaction with their work. With these, Chandra (2004) emphasized the need for ongoing professional development of teachers to enable them to be at the forefront not only of pedagogical techniques but also of school curriculum and communications technologies.

Some multigrade teachers in Finland believe that there are many advantages to multigrade instruction: "The small size of combined grades compensates many instructional difficulties. Age-wise heterogeneous groups are natural bodies where the members educate each other. The older pupils in a combined grade may function as instructors to younger ones (Pied la, 1978). However, materials preparation for use with flexible grouping makes a great demand on teacher time because materials must be explicit, readable, unambiguous and coherent. Materials must "include the elements which lead to critical thinking and develop an evaluative approach in the pupil.

Furthermore, Multigrade teachers give greater time for the demands on teaching in a multiple grade. Quality teachers need to spend more time in planning and preparation. This often means modifying the existing grade level materials to ensure students will be successful. In addition, teaching a broad range of grade levels in the same classroom is complex and demanding. For instance, one teacher juggles all those grades with their wide levels of student maturity, ability and motivation. Other teacher prepares for the many curricular areas, meet individual student needs and have time to eat lunch. Likewise, with many successful teachers and students who are living proof that mixed grade classes are viable organizational structures for learning. Although empirical studies of these classrooms are quite scarce, enough descriptive literature exists to illustrate both the complexity and the rewards of the multigrade classroom. Dodendorf (1983) conducted a study of a Midwestern rural two-room school where 35 students, spanning five grades, were taught. The classroom was organized into two rooms. The "lower" room contained students in grades K-4 while the "upper" room contained students in grades 5-8. Clearly, Dodendorf's study suggests such implication that success depends on the ability of the teacher to organize and manage instruction so that cooperation, independence and a motivation to learn become environmental norms.

Multigrade teachers find the implementation of an educational innovation difficult because they must change the core of educational practice -a pedagogy that multigrade teachers do not know or in which they did not receive any training or support (Benveniste \& McEwan, 2000). This has a severe impact on the potential of multigrade schools to play an important role as educational units in underserved rural areas. The teachers in multigrade schools must be provided with adequate knowledge of and training on how to handle several grade levels at the same time. Therefore, training and in-service teacher education programmers need to prepare, guide and support multigrade teachers to build a knowledge base that enables them to have a thorough understanding within the complexity of the actual classroom situation and to help them use a variety of teaching strategies in a multigrade context (Lingam, 2007).

According to Pincas (2007), successful multigrade teachers, to foster pedagogy that "enhances learning in another", must be characterized by effective peer instruction; self-directed learning; the development of learning to learn skills; exposing learners to work at other levels; learners doing constructive work while waiting for the teacher's attention; and adequate resources to cope with the needs of different groups. Yet, Burns et al, (1989) cited by Diosdada Boiser use variety of terms to name what they are trying to describe such as "teacher traits, "teacher personality", "teacher performances", "teacher outcomes". A warm teacher would have different effects on the students according to age, sex, achievement level, socioeconomic class, ethnic group, subject, and classroom context. These differences tend to operate for every teacher characteristics and to affect every study on teacher behavior. Although teacher characteristics may be suitable for a particular study, the characteristics as

98 Consortia Academia Publishing (A partner of Network of Professional Researchers and Educators) 
well as the results cannot always be compared with another study.

Burns stated Important Characteristics for Successful Teacher: The teacher is said to be resourceful in making materials with Originality, creativeness, initiative imagination, adventurousness and progressiveness. Teachers also possess Intelligence in fore sighting things with intellectual activity, understanding mental ability, intellectual capacity and of great common sense. Moreover, Teachers should be Emotionally Stable and maintain poise, self-control, steadfastness, sobriety, dignity, non-neurotics, emotional maturity, adjustment, constancy, loyalty, and easy going realism in facing life, not excitable, stable and integrated character. It is also been widely known that teachers are considerate being because in the classroom they are appreciative, kind, friendly, courteous, sympathetic, tact, good natured, helpful, patience, polite, and thoughtful. In addition, teachers are Buoyant and Optimistic, enthusiastic in each day, cheerful with the learners, gregarious at stakeholders, fluent in the lesson presentation, has sense of humor, pleasant to unpleasant situations, carefree even if risk is at hand, vivacious and alert in animating thing, articulates in better ways, support ideals, expressive in instilling values and witty at all times necessary. Teachers possess objectivity in terms of fairness in assessing learners, and free from prejudice. Other qualities that the teacher has is driven physical vigor, energetic, industrious, and quick. Teachers also are Dominant oozing with Self-confidence, force, independence, insensitiveness to social approval, self-sufficient, determined, self-reliant, and self-assertive.

Unfortunately, little evidence is available in the international literature relating to the process of support and preparing teachers and schools as they gradually learn, come to understand, become skilled and competent in the use of new ways, ensuring growth, improvement and support in a multigrade context. According to some famous Multigrade researchers, the possible reason according to Little (2006) is that in most countries teacher education for multigrade education does not exist at all or (Pridmore \& Bajracharya, 2006) is not embedded in their teacher education curricula nor offered as part of in-service training. Vithanapathirana (2006) reported that in many of the in-service training programs in multigrade education, a cascade model of dissemination is adopted and therefore are subject to many of the effectiveness issues that face cascade training programs in general.

\subsection{Content}

Shaeffer (2014) specifies that multigrade classroom managed by a single teacher who is responsible for the class which is composed of two or more grade levels or group of learners where the content of teaching-learning methodologies is active, child centered, participatory, cooperative, and self-paced with peer tutoring across grade levels as well as teachers prepare materials that are in line with the curriculum and should be theme-oriented. Thus, mutigrade classroom serves as an environment that will make the child the focus of the learning process where seating arrangements are adjusted to the learners' preferences; and that teachers are facilitators, motivators, and resource person in the community rather than being the traditional source of knowledge.

Multigrade Classroom is a "one size fits all" that teacher put and teach all the same level with differentiated instruction design to have students work at different levels in different groups and on different task in the classroom. Effective multigrade classroom is based on giving importance of the content in organizing classroom schedule and space as economically as possible, maximizing children's full potential in providing learners opportunity to learn, generates challenging and focused pupil-teacher instruction (Coetzee et al., 2015).

Research says Multigrade classroom content is not easy to make. Teachers require a lot of proper planning and research. Many teachers are reluctant to abandon their current teaching style to try something different (Boonzaaier, 2008). Moreover, multigrade classroom needs to be more structured because teachers need to organize students working on several different tasks. Multigrade schools are often located in remote and difficult to reach areas. Also, most teachers view multigrade teaching as unavoidable nuisance where they will have negative outlook and impression; thus teachers maybe resistant in the idea of being trained in multigrade methods, and motivation are low. There is a need, therefore, to convince teachers and other in the field of education in the merit of multigrade pedagogy and give importance to its content (Poidexter, 2010). 


\subsection{Connection}

Mutigrade education is a connecting journey starting from design, to conformance, and ends at better performance. Indeed, it is a never ending performance. A good quality education is one that provides connection to all learners with capabilities they require to become economically productive, develop sustainable livelihoods, contribute to peaceful and democratic societies and enhance individual well-being (Miles, 2012). The learning outcomes that are required vary according to students' connection of the basic education cycle that include threshold levels of literacy and numeracy, basic scientific knowledge and life skills including awareness and prevention of disease. Moreover, Capacity development to improve the quality of strong connection to the learners and other education stakeholders are important and a crucial process all throughout (Gerdabi, 2013).

Furthermore, Barret et. al (2006) cited by (Zhu, 2014) a quality education is one that focuses on the whole child-the social, emotional, mental, physical, and cognitive development of each student regardless of gender, race, ethnicity, socioeconomic status, or geographic location. Preparing the child for the future and create things skillfully. The must of providing resources and directs policy to ensure that each child enters school healthy and learns about and practices a healthy lifestyle; learns in an environment that is physically and emotionally safe for students and adults; is actively engaged in learning and is connected to the school and broader community; has access to personalized learning and is supported by qualified, caring adults; and is challenged academically and prepared for success in college or further study and for employment and participation in a global environment.

Elias (2011), a quality education also provides the outcomes needed for individuals, communities, and societies to prosper. It allows schools to align and integrate fully with their communities and access a range of services across sectors designed to support the educational development of their students. A quality education is supported by three key pillars: ensuring access to quality teachers; providing use of quality learning tools and professional development; and the establishment of safe and supportive quality learning environments. Quality Education is just that - an education that serves each child pedagogically and developmentally. An education that is inclusive and is structured to realize the potential of each child regardless of location or economic status (Welch, 2000).

On the context of the quality of Multigrade Education, researches are quite rare. Thus studies of Prat (1989) stated that multigrade students performed consistently higher in mathematics, reading and language than did single-grade students. He also reported that quality of multigrade classroom in terms of student attitude towards self, school or peers are higher than those of monograde. Multigrade instructions contribute a great impact to students sharing and imparting knowledge to their classmate when they applied peer tutoring. Thus, promoting meaningful engagement among learners in the classroom and develop sense of responsibility for their own learning (Talo \& Mncube, 2012). It also promotes cooperative learning (Gawe, 2011) where small group learners are engaged in a collaborative task thus promotes accountability among learners as they are responsible for making sure that learning took place and (Berry, 2001) it allows educator to assign work to groups of students in the knowledge that they will then be able to work productively.

On the other hand, Joyce (2014) in her journal Quality of multigrade education in rural areas stated that to have achieve such, teachers need to have a complete set of proper trainings on the teaching and enhancing lessons that will capacitate them with the wit and skills to manage the different levels of group learners simultaneously. (Koulouris \& Sotiriou, 2006) said that training will remains the only option for teachers in multi-grade schools to give effective teaching and learning to take place. Teachers need to be developed through in-service training workshops to ensure that they know how to handle multi-grade classes (Brown, 2010).

\subsection{Character}

Quality of multigrade education as to the pedagogy through which educational quality is most directly mediated through educators' character in the four corners of the classroom. According to Alrajhi et al. (2015) 
some of those who insist that specialist expertise is necessary for handling the complexities of access, enrolment, retention and outcomes. Moreover, these can be quantified and exercise no such caution about pedagogy, cheerfully peddling unexamined certainties about the conditions for effective teaching and learning (Jomtien World Declaration on Education for All, 1990).

Considering the statement of UNESCO (2000) that quality is once again defined in terms of outcomes rather than process. Quality means education and education means quality for it means anything it means satisfying basic learning needs and enriching learners' lives through teachers' character to meet the demand on the globalization of education. Furthermore, the quality education for all develops healthy, well-nourished and motivated students; well-trained teachers and active learning techniques; adequate facilities and learning materials; a relevant curriculum that can be taught and learned in a local language and builds upon the knowledge and experience of the teachers and learners; an environment that not only encourages learning but is welcoming, gender-sensitive, healthy and safe; a clear definition and accurate assessment of learning outcomes, including knowledge, skills, attitudes and, values; participatory governance and management; and respect for and engagement with local communities and cultures. Additionally, educational quality of multigrade talk not about test scores but is all about educational learning experience that took place by which dwelling on their attitude to the tasks set and the degree to which they find the context of peer and teacher-student relationship rewarding and supported (Rudduck et al., 2006).

\subsection{Theoretical and Conceptual Framework}

This study got background from the Japanese basics in primary schools which are three Cs. Content, Connection, and Character with the goals or developing children's friendship, belonging, and social development. It is said that school is a place of deep human connections, children are motivated to be the best people they can. Japanese Elementary teachers focus seriously on social development when the values of friendship, cooperation, and responsibility are taken seriously (Monbushu, 1989) a feeling of intimacy with the people in the school and to enjoy the classroom life; Teachers insure that school then have become a better place for learning and for developing friendship.

When teachers paired the content down for the learners to have plenty of time to clearly see the meaning and importance in what they learn, teachers teach students to likely develop their strong connection to school. Moreover, Japanese teachers expect when school meets children's needs, children will naturally be motivated to take on the values of the school in every school day activity. In contrast, this study focused on how the travails of multigrade teachers in the Division of Southern Leyte how they sustained strong connection to the delivery of quality education; effectively deliver content to two, three or more grade levels in one classroom; and how the teachers professionally characterized the expectations for effective implementation of multigrade education.

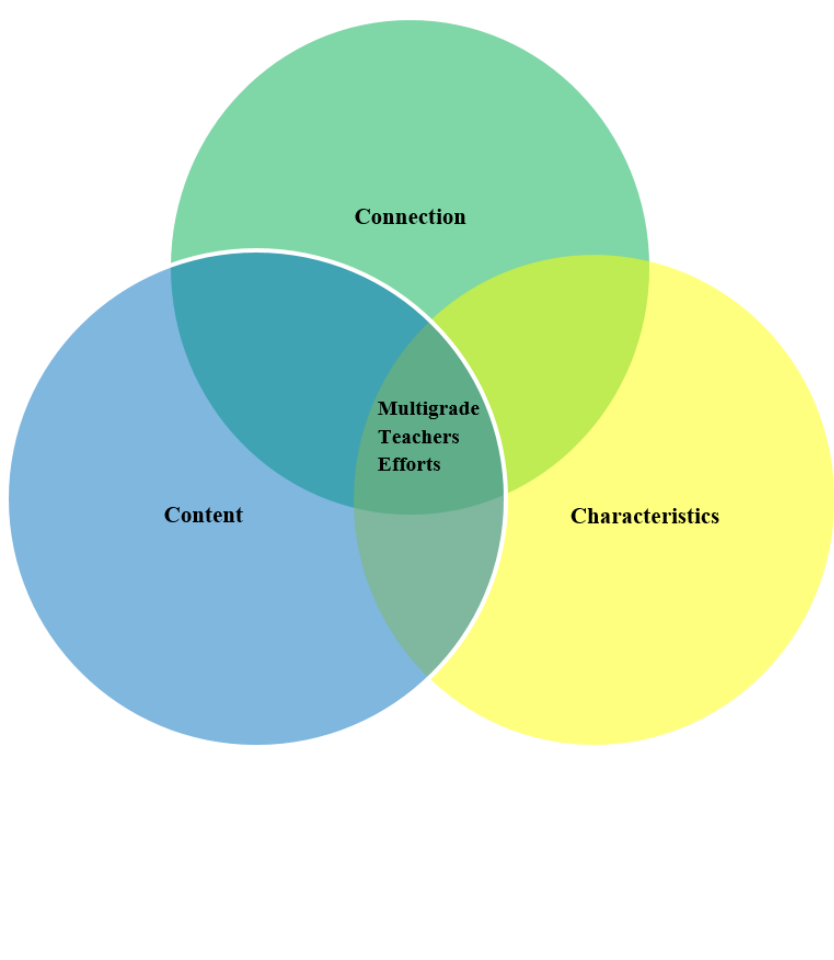




\section{Method}

Research design - This study utilized the qualitative phenomenological design of Edmund Husserl which is concerned with attending the way things appear to individuals' experience. It focused on how people perceived and take objects and events, rather than describing phenomena according to predetermined categorical system, conceptual and scientific criteria. The researcher investigated how individuals made sense of their experiences. This involved 'bracketing' one's preconception and allowing phenomena to speak for themselves. Researches attempted to understand what it is like to stand in the shoes of the subjects and which will influence the extent to which they get access to the participant's experiences and how they will make sense of the subjects' personal world (Smith \& Osborn, 2008). The discipline of phenomenology may be defined initially as the study of structures of experience, or consciousness. Literally, phenomenology is the study of "phenomena": appearances of things, or things as they appear in our experience, or the ways we experience things, thus the meanings things have in our experience. Phenomenology studies conscious experience as experienced from the subjective or first person point of view. Phenomenology is given a much wider range, addressing the meaning things have in our experience, notably, the significance of objects, events, tools, the flow of time, the self, and others, as these things arise and are experienced in our "life-world". This field of philosophy is then to be distinguished from, and related to, the other main fields of philosophy. The study used approaches of ontological (the study of being or what is), epistemological (the study of knowledge or how we know), methodological (study of how it is being done), axiological (study of right and wrong, how we should act) and eschatological (study of final judgement or how it ends). For the purpose of this study, phenomenological research was used to explore, narrate and document the travails of multigrade teachers in providing quality education.

Research environment and participants - For this study, the research environment involves the Multigrade Schools in the Division of Southern Leyte. The Division of Southern Leyte consists of 4 IADS namely IAD 1, IAD2, IAD3 and IAD4. IAD1 consist of 5 districts which are Macrohon, Padre Burgos, Malitbog, Tomas Oppus and Limasawa. IAD2 consist of 5 districts which are Bontoc 1, Bontoc 2, Sogod 1, Sogod 2 and Libagon. IAD3 consist 4 districts namely Liloan, San Francisco, Pintuyan, and San Ricardo. And IAD4 consists of 6 districts namely Saint Bernard, San Juan, Anahawan, Hinundayan, Hinunangan and Silago. There were 31 totals of participants where in IAD 1 there were 8 participants; in IAD 2 there were 7 participants; in IAD 3 there were 9 participants and in IAD 4 there were 7 participants.

Research instrument - This study used an open-ended questionnaire that solicit information on the travails of multigrade teachers. Part I is the Profile of the Respondents such as name, sex, age, civil status, localization of the School and other designations. Part II is dealing with the 5 levels of deepening questions on the approach of Ontological, Epistemological, Methodological, Axiological and Eschatological art of questioning.

Data gathering procedure - The researcher asked approval from the Office of the Graduate Studies to conduct the study. A letter was sent to the Schools Division Superintendent to ask permission to conduct the study and to the District Supervisors of IAD 1, 2, 3, 4 for the same purpose. The researcher seeks the participant's availability of time for the distribution of the open-ended questionnaire. The open-ended questionnaire was used in three modes: First, as interview guide for selected multigrade teachers in the District of Malitbog during the Gender and Development seminar last week of January 2018 where the researcher had the chance to solicit information that contributed a lot to this study. Second, as interview guide for group discussion during the UGMAD seminar of the teachers in the Division Office last February 2018 where the researcher got the chance to get essential information's for the study. The answers were put into notes. Last, as questionnaire with written response where researcher used frequently to get and elicit significant information. During the distribution of the questionnaire, some were sent and retrieved via Facebook messenger and email because some of the respondents preferred to have their responses typewritten and interviewed through cellphones. Upon doing the interview, the researcher made sure and provided assistance to ensure that each respondent could clearly provide answers to the questions. Dalli (2008) points out that the research participants were respected, and culturally appropriate processes were followed in the conduct of the study. 
Qualitative data analysis - Data analysis was performed following Corbin and Strauss (2008) grounded theory (open coding, axial coding and thematic) where conceptual labels placed on discrete happenings, events, and other instances of phenomena. In open coding, it is where the process of breaking down, examining, comparing, conceptualizing, and categorizing data. Axial coding consists of identifying relationships among the open codes. Thematic coding is locating in relation to other qualitative analytic methods that search for themes or patterns based on the three C's. These steps helped the researcher and interpreted the data and draw meanings out of it.

\section{Presentation, analysis, and interpretation of data}

\subsection{Content}

Teachers are known to be knowledgeable with their respective field in teaching and its content including the multigrade teachers in different parts of the world. The knowledge of the content of pedagogical theories and applications concerning on what to teach as prescribed in the curriculum guides must be delivered holistically. Thus, the table 1 shown in page 25 will help to determine the efforts and hurdles of the multigrade teachers. Each discussion is anchored on major themes: Content and delivery of requires sufficient tools and resources; Content and delivery requires High demand for time management; MG Teachers need more trainings and seminars to equip them in handling diverse classes in one classroom but may not jeopardize their classroom instructions; Adapting curriculum; Structuring lesson plans in a one-shot method; using necessary techno-materials; Developing teaching and learning materials and group them strategically; Teachers provide and conduct active learning activities and opportunities to ensure that students participate in the learning process; using flexible method such as cooperative learning; peer tutoring; teacher lead instruction and self-reading study; The teacher agrees that MG education has the right to quality education. Teachers' method of teaching is the same as in monograde education; An MG teacher has a demanding work in providing teaching and learning materials.

\section{Teachers' view in terms of content on Multigrade Education}

\begin{tabular}{|c|c|c|c|c|}
\hline Ontological & Epistemological & Methodological & Axiological & Eschatological \\
\hline $\begin{array}{l}\text { What are } \\
\text { the } \\
\text { teachers' } \\
\text { view of } \\
\text { content and } \\
\text { its } \\
\text { delivery? }\end{array}$ & $\begin{array}{l}\text { What are } \\
\text { the } \\
\text { evidences } \\
\text { of teachers' } \\
\text { perspective } \\
\text { of content } \\
\text { and its } \\
\text { delivery? }\end{array}$ & $\begin{array}{l}\text { What are } \\
\text { the feelings } \\
\text { of success } \\
\text { after issues } \\
\text { were } \\
\text { addressed? }\end{array}$ & $\begin{array}{l}\text { What have } \\
\text { been done } \\
\text { to address } \\
\text { the issues } \\
\text { regarding } \\
\text { content and } \\
\text { its } \\
\text { delivery? }\end{array}$ & $\begin{array}{l}\text { Where the } \\
\text { teachers } \\
\text { efforts done } \\
\text { safeguard } \\
\text { the quality } \\
\text { of MG } \\
\text { education? }\end{array}$ \\
\hline $\begin{array}{l}\text { *Content and } \\
\text { delivery of } \\
\text { requires sufficient } \\
\text { tools and } \\
\text { resources. } \\
\text { *Content and } \\
\text { delivery requires } \\
\text { High demand for } \\
\text { time management } \\
\text { *MG Teachers } \\
\text { need more } \\
\text { trainings and } \\
\text { seminars to equip } \\
\text { them in handling } \\
\text { diverse classes in } \\
\text { one classroom but } \\
\text { may not } \\
\text { jeopardize their } \\
\text { classroom } \\
\text { instructions }\end{array}$ & $\begin{array}{l}\text { *Adapting } \\
\text { curriculum } \\
\text { *Structuring } \\
\text { lesson plans in a } \\
\text { one-shot method } \\
\text { *Using necessary } \\
\text { techno-materials }\end{array}$ & $\begin{array}{l}\text { *Developing } \\
\text { teaching and } \\
\text { learning materials } \\
\text { and group them } \\
\text { strategically. } \\
\text { *Teachers provide } \\
\text { and conduct active } \\
\text { learning activities } \\
\text { and opportunities to } \\
\text { ensure that students } \\
\text { participate in the } \\
\text { learning process; } \\
\text { using flexible } \\
\text { method such as } \\
\text { cooperative } \\
\text { learning; peer } \\
\text { tutoring; teacher } \\
\text { lead instruction and } \\
\text { self-reading study. }\end{array}$ & $\begin{array}{l}\text { *The teacher } \\
\text { agrees that MG } \\
\text { education has the } \\
\text { right to quality } \\
\text { education. } \\
\text { *Teachers' method } \\
\text { of teaching is the } \\
\text { same as in } \\
\text { monograde } \\
\text { education. }\end{array}$ & $\begin{array}{l}\text { *An MG teacher } \\
\text { has a demanding } \\
\text { work in } \\
\text { providing } \\
\text { teaching and } \\
\text { learning } \\
\text { materials. }\end{array}$ \\
\hline
\end{tabular}


Content and delivery of requires sufficient tools and resources - Most schools with multi-grade classes do not have adequate resources. As a result, multigrade teachers craft self-made learning materials that are available in the locality they are working in because their job is to ensure that learning materials are used because these are very important tools in facilitating learning. In developing teaching and learning materials, multigrade teachers find it difficult to devise or thought of on their own and link them to the bigger objective of an education program. That means that they have to link with other teachers, use varied tools and resources which are essential for teaching. Varied tools such as LED TV or SMART TV for video presentations and electronic teaching materials such as slide deck presentation and drill materials used in teaching.

In most cases, teachers lack resources in integrating technology in the classroom so they developed alternative varied tools such as stick pictures, clip-arts and graph. Multigrade teachers believe that a picture is worth a thousand words. For instance, a teacher's desire to help learners really grasp a concept may consider incorporating drawings to textual materials that will be presented in the classroom to visually represent the different theories; topics and areas of learning that are to be taught. Using visual facilitation and pre-drawn flip charts/clip-arts not only helps draw in learners (so to speak), but makes it easier for them to remember the concepts they've just learned. The simple pictures and the words about the topic offer an easy way for learners to link the concept to the picture (Stancampiano, 2013). In such ways, it will help in maximizing and managing the time.

Content and delivery requires high demand for time management - Teachers need to balance the long-term goals of the classroom, the immediate educational needs of the students and the large volume of paperwork that comes with every assignment. Between writing lesson plans, grading exams and actually teaching, teachers often feel that it is impossible to fit everything into the allotted time frame (Room, 2013). For instance, a teacher was assigned to teach kindergarten, grade 1 , grade 2 and grade 3 classes everyday with all the subjects prescribed in the curriculum which means the teacher must prepare lot of lesson plans a day or a night before the class. Making and crafting lesson plans are not easy in order to cater all diverse needs of the learners in a diverse classroom in the allotted time. The preparations come with a lot of understanding on each competency and on how to deliver it appropriately. MG Teachers need more trainings and seminars to equip them in handling diverse classes in one classroom but may not jeopardize their classroom instructions

According to Phelps (2008) curriculum knowledge involves many programs in which teachers have to engage so as to gain knowledge of what they should teach. Since, being a multigrade teacher is not an easy job to do and accepting the job which they are not well-prepared for lack of trainings and exposures considering that these were not provided by the degree program that they had pursued. Multigrade teachers have a critical duty so as to say because they must have the knowledge of the curriculum that they present to the learners. The methods that multigrade teachers in the classroom are said to be undefined because they need to shift to other strategies that are best suited to their diverse learners. Allen (1995) asserted that in all learning environments, students bring with them diverse experiences which are translated into different behaviors and actuations that the teachers should take into considerations. Learners' age, ability, developmental level, background, experience, motivation and reflect some of the diversities found among students, and which need to be appreciated by teachers.

Moreover, the knowledge on appropriate techniques of multigrade teachers are drawn from some of their experiences and they adapt to it for as long as it is applicable. But the challenges come in when diversity of learners widen which means multigrade teachers needs to adapt more different skills and knowledge in handling MG class. The needs of proper and appropriate seminars conducted by the Department of Education here in the Philippines is very important to give our multigrade teachers an update of latest innovative strategies and approaches in handling MG classroom scenarios. The knowledge on deciding what to teach, how to teach, and when to teach is the adaptive competence that multigrade teachers have to developed in order to facilitate teaching and learning efficiently and effectively. Schulman (1986) states that it is expected that a professional teacher will be familiar with the curriculum materials so that he/she can deliver well and carry out the goal in the learning process. 
However, sending teachers to seminars and workshop during school hours may jeopardize the students' opportunity and right to education. When a multigrade teacher who handles 3 classes will have to leave his/her class because he/she is called for a seminar, the teacher will leave the students. That would mean that the classes are suspended and pending of expected competencies to be learned by students. On the other hand, training remains the only viable option for teachers in multi-grade schools for effective teaching and learning to take place. Teachers need to be developed through in-service training workshops to ensure that they know how to handle multi-grade classes. For example, teachers need to know that when they handle one grade in the class, they should give group activities or individual activities to the other class learners. These activities need to be monitored with the help of the gifted learners in the classroom. This could also promote independent learning. This should be done to ensure that discipline is maintained in the class because when learners are idling they tend to be out of control. It should be pointed out that the responsibility of the teacher increases in setting up the apt classroom situation and he/she can do that if he/she has received proper training.

“Way klasi among mga bata labina ug ipada mi ug seminars, unja maajo raba ug ang kana nga seminars para na sa multigrade teaching peru dili man. Seminar sa lain pang trabahuonon sa teacher".

[Our students don't have classes and if we are out for seminars, it will be helpful if the seminars we are into are for multigrade but it is not. It's a seminar for another related works for a teacher]

Teachers need to be provided with opportunities for continuous professional development through a number of different training that are appropriately foster the improvement of personal competences in multi-grade teachers (Matchidiso, 2014).

Adapting the curriculum - Multigrade Teachers adopt the curriculum of the monograde classes and reviewed the prescribed curriculum guides in the making of their lesson plans so that they will know what objectives are similar and are related between or among grade levels. Actually MG teachers write the lesson plan based on the pre-assessment results, they have to determine first what teaching scheme or way of teaching will be used. The objectives/skills to be developed in all the groups will tell what scheme is the most appropriate. The teaching scheme will likewise suggest the format of the lesson plan. When the objectives of all the groups are common in terms of behavior and content, only then will a multigrade class will be handled in a one-shot teaching in the developmental phase, but content materials from the three grade levels will be used. In the presentation of the lesson use the Material of the lowest group first (e.g. Grade I Material): followed by the material of the next group (e.g. Grade 2 Material), then of the material of the last group (e.g. Grade III Material). In application and evaluation, give differentiated self-directed, self-checking and self-scoring seatwork exercises to the three groups. Then give on the spot corrective instruction one after the other.

Structuring lesson plans in a one-shot method - Teachers use the one-shot planning; they cannot deny the fact that they have to deal with factors that affect the students such as limited learner's material. The scarcity of the material would cause burden to the teacher because they have to reproduce activity sheets in which expenses incurred are paid from pennies drawn out from their own pockets. Another issue on instructional materials is focused on the localization concern, because as suggested, teachers need to use localized, colorful, and artistically made materials to get the learners attention. Localized materials are very useful to students because it provides opportunity for the learners to embrace their own national language for them to be good communicators (Castillo, 2016), believed that the inclusion of culturally rich materials (target culture) can affect the cultural identity of learners.

Seng (2014) stated that color has proven to support the learning process, can reduce eyestrain \& fatigue and color is believed to be the most important visual experience to human being. It functions as powerful information channel to the human cognitive system and has been found to play a significant role in enhancing memory performance; thus color is one of the important elements in influencing learners' attention. Colored materials and 
books can attract students to read the books up to $42 \%$ more often than the non-colored books. This shows the importance of color in making the information or message more attractive to the public (Dzulkifli, 2013).

Using necessary techno-materials - In teaching, traditional way is not those effective in the 21 st century learners. In adept to the new curriculum in education, using technology as part of the classroom instruction is the new trend and a must to do in order to get the attention of the learners. According to Bruyckere (2016) In education, we have the feeling of finding harder and harder to reach the students that is why the interest in smartboards or learning platforms including slide deck and video presentation or anything new on the market that might help. Moreover, using technology in the classroom improves engagement of the learners, improves knowledge retention on their lessons, encourages individual learning, encourages collaboration, students can learn useful life skills through technology, and beneficial to the teachers as they will not take so much time in preparing lessons and materials for their teaching because there's more in internet can offer.

Developing teaching and learning materials and group them strategically - Making teaching and learning materials always considers strategic grouping or also known as flexible grouping for delivering instruction. It can be as a whole class, a small group, or a peer-pairing. Flexible grouping creates temporary groups that can last an hour, a week, or even a month. It's not permanent, but it is a temporary way for students to work together in a variety of ways and configurations depending upon activity and learning outcomes (Cox, 2018). The fact that multilevel classrooms are already grouped according to grade levels, the teacher also creates group strategies that corresponds to each levels of learners. This poses such a challenge for teachers to be teaching 3 to 4 grade levels in a day which within each level, and to implement differentiated instruction and activities that will fit the individual capacity of the learners in a group. But MG teachers make sure of making and crafting those learning materials which are parallel to the content prescribed by the Department of Education. Moreover, activities and learning materials of a composite education are concerned by stages of skill set, and not ages of the learners. By these students are able to work to their own pace of developmental level, rather than expecting their grades. Meaning, students are focused and concerned with their acquired learning provided by the teacher's instructions and differentiated activities which are strategically done through small and big groupings.

Teachers provide and conduct active learning activities and opportunities to ensure that students participate in the learning process; using flexible method such as cooperative learning; peer tutoring; teacher lead instruction and self-reading study.

"I prepare many activities, study the lesson and find instructional/learning resources due to lack of LM's most especially in grade 1. Other content in LM or TG does not jive the competencies prescribed in the CG that could have me a headache".

Active learning means students are engaging with the material, participate in the class, and collaborate with each other. It could not be expected for students to simply listen and memorize; instead, they should demonstrate a process, analyze an argument, or apply a concept to a real-world situation (Sudhakar, 2018). Multigrade Teachers should incorporate active learning strategies into every component of the topic. For example, encouraging short partner discussions during lectures (i.e., think-pair-share) which is very helpful in learner's progress to understand the lesson very well. Some teachers do the led-instruction (using of powerpoint flashed through tv screens) to let the students do the task of better participation and experiential learning. It is much better to ask some questions with higher order thinking skills such as why and how questions to develop their ideas in creating reasons. If you are MG teacher teaching a lecture on that day, set aside time during each lecture to ask and answer questions, to ask students to solve a problem, or to discuss an issue. Pause every 15-20 minutes for this purpose. When students learn to expect these opportunities for discussion or questioning, they will listen more actively to the lecture. If you lecture for 45 minutes before you pause for questions or discussion, your students listen for so long that they may find it difficult to switch modes quickly. Furthermore, they may well have forgotten questions, comments, or unclear concepts from the earlier parts of class (Raferty \& Griffin, 2004). 
Furthermore, active learning strategies serve a two-fold purpose: they make the classroom a dynamic, ever changing environment in which students have a voice, and they allow students to view teachers as people who are flexible enough to take risks in the classroom. Remember that your willingness to take risks in the classroom increases the likelihood of your students doing the same. Students do not learn much just sitting in classes listening to teachers, memorizing prepackaged assignments, and spitting out answers. They must talk about what they are learning, write reflectively about it, relate it to past experiences, and apply it to their daily lives. They must make what they learn part of themselves (Chickering \& Gamson, 1987).

Multigrade teaching is all about classroom organization, student management, and, ultimately, the successful transmission of grade specific curricula. It is the responsibility of a multigrade teacher to plan and organize classroom to get the best results from the space and resources available. The key to planning, designing, and managing ranges from both grade-appropriate and mixed-grade activities for children to keep them engaged in learning. However, ideally the multigrade teachers can do a lot of what has been mention above. The quality of education that the teacher will be giving depends largely on how smooth the class instructions are without interruptions by other grade levels misbehaviors. Teacher's efficiency and effectiveness rest on creating a classroom conducive to learning by developing exciting and stimulating activities ranging from group work to independent study. The teacher agrees that MG education has the right to quality education.

Teachers' method of teaching is the same as in monograde education - The Philippine Government has the responsibility to provide free basic Education for All (EFA). The Multigrade Class is an answer to the problem of access to education for our children in the remote and isolated villages of the country. The multigrade teachers are the key factors in providing meaningful learning experiences in these classes in order to sustain pupils' interest and make learning more effective. Some teachers would agree that MG education has the right to quality education when they never mind its challenges but still focus on its advantages such as: maximum social interaction between/among peers; cooperative learning predominant; will learn to be independent, self-directed learners can learn to be more resourceful; prepared for real-life situations where there is constant interaction between people of different ages, varied skills and abilities; can learn to assume leading or supporting roles as needed in different work situations; stigma associated with failure and repetition is removed; girls who are often expected to stay home or at least to close to home to take care of younger siblings or the household will have more chances to go to school since school are located within the community; and evidence suggests that multigrade students can attain higher achievement levels especially in math, science and language.

"For me, some point it is, because we only have small learners so I can assess or cater them immediately".

"Yes because I am following the monograde system. The strategies needed by the multigrade teacher should be the same strategies used in monograde classes".

"Somehow, something, sometime. But not totally".

Some multi-grade teachers, pattern their ways of teaching to monograde based on the single curricula that mono-grade and multi-grade used as basis in teaching. The learning competencies of the monograde class are just the same with the multi-grade class. An MG teacher has a demanding work in providing teaching and learning materials.

$M G$ teacher is always stressed in finding sources and techniques for what's best in the teaching-learning”.

Multi-grade teaching in many views represents a more demanding teaching situation and special attention should be given to it. Frequently multi-grade teaching is required not by choice but through force of circumstances. Due to the undying issue of the Department of Education which is the lacking supply of learner's materials, multigrade teachers double or triple their efforts and time in working and making materials as well as research 
anything that will be of great help in the teaching-learning process. They frequently expense higher amount of money just to ensure that they provide the significant materials during their lessons administration considering the needs of the learners. Teachers in MG class always look into perspective of "will one shoe fits all". Will these materials be enough? Will my instructions be accurate and understandable? Those are the few questions that MG teachers always utter during their whole years as an MG teacher.

The main reason for MG teachers in always mining for resources is because until now there are no created accurate and appropriate programs for the multigrade class. Preparations will always fall into innovations and benchmarking that multigrade teachers always do every now and then. Ngubane (2012) articulates that curricula across the globe are not structured for multigrade teaching, which causes teachers to struggle assistance or guidance from departmental officials is minimal. Futhermore, Brown (2010) states that multi-grade teachers are unable to adjust the single-grade curriculum to a multigrade context which thereby contribute intensely to the contextual challenges that teachers are facing.

"Gulong-gulo ang utok kanunay sir ug unsaon napud ang himuon sunod kay arun di gihapon kapunay ug si-aw mga bata". (Mind is always having difficulty on what to do next to avoid student's misbehaviors.)

"Mao lage na sir nga kapunay ug himo or adjust para makaajo sa mga bata bisan si-aw ug dili participative ang uban mao lage nga lisud pag instill ug quality education kay di baja lalim maghimog materials kay it will take time, gasto kaajo". (Always making and adjusting things for the welfare of our students even if others are not participative and hard to instill in them quality education which cost more money and will take time in making materials.)

"Usahay gani sir nuh, labinag kapoy kaajo kay tungod sa sapaw-sapawnga buhatunon, unja behind na lmn kaajo, laktawan na lamn ang ubang lessons arun makaapas unja di na mahimuan ug mga sakto nga activities". (Sometimes, if too weary and bombarded by the task and things to be done, skipping other lessons will be the options just to cope up behind targets. Thus, cannot make good activities.)

By that, multigrade education in terms of preparation takes so much of their time, money and resources just to promote quality education even though impossible to attain because of such things that hinders the objectives and will come along the way unexpectedly.

\subsection{Connection}

Being an effective multigrade teacher, the need of strong connections to the learners will always be on top priority to address the needs of each learner's. These are the efforts of the multigrade teachers to provide connection to the learners in giving quality multigrade education. Teachers have difficulty in managing two or more classes due to difficult levels of learning and competencies. MG education does not entirely assure a good quality education. Teachers are having a hard time providing the desired needs of the students due to factors that affect the student's level of learning and competencies, and because of overlapping activities. Teachers encountered and taught children with different learning abilities and difficulties, with different norms and living condition. Teachers deal with these by committing demonstrating sensitivity to each student's uniqueness and by using positive discipline. Keeping a checklist to follow how students are spending time during school hours and the activities that have the most time. Encouraging each student to explore ask questions, show inquisitiveness to learn something new, and learn by doing and through playing. Teachers are proud being a multigrade teacher. And placing children at the center of the attention by giving rewards helping them progress through their own stages of learning at their own pace and speed.

Teachers had the difficulty in managing 2 or more classes due to difficult levels of learning and competencies - Multigrade teachers' teaching two or more grade levels simultaneously are difficult to manage 
considering the learning abilities of the students. Teachers have to organize group and manage them accordingly. Mostly in multigrade classes, cooperative learning style is frequently used because it will provide each member of the group to do their assigned task. Everyone in the group is working with each other to make some significant and wonderful outputs.

\section{Teachers' view in terms of connection on Multigrade Education}

\begin{tabular}{|c|c|c|c|c|}
\hline Ontological & Epistemological & Methodological & Axiological & Eschatological \\
\hline $\begin{array}{l}\text { What are } \\
\text { the } \\
\text { teachers' } \\
\text { view of } \\
\text { connection } \\
\text { and its } \\
\text { delivery? }\end{array}$ & $\begin{array}{l}\text { What are } \\
\text { the } \\
\text { evidences } \\
\text { of teachers } \\
\text { perspective } \\
\text { of } \\
\text { connection } \\
\text { and its } \\
\text { delivery? }\end{array}$ & $\begin{array}{l}\text { been done } \\
\text { to address } \\
\text { the issues } \\
\text { regarding } \\
\text { connection } \\
\text { and its } \\
\text { delivery? }\end{array}$ & $\begin{array}{l}\text { What are } \\
\text { the feelings } \\
\text { of success } \\
\text { after issues } \\
\text { were } \\
\text { addressed? }\end{array}$ & $\begin{array}{l}\text { Where the } \\
\text { teachers } \\
\text { efforts done } \\
\text { safeguard } \\
\text { the quality } \\
\text { of MG } \\
\text { education? }\end{array}$ \\
\hline $\begin{array}{l}\text { *Teachers have } \\
\text { difficulty in } \\
\text { managing } 2 \text { or } \\
\text { more classes due to } \\
\text { difficult levels of } \\
\text { learning and } \\
\text { competencies. } \\
\text { *MG education } \\
\text { does not entirely } \\
\text { assure a good } \\
\text { quality education. } \\
\text { Teachers are having } \\
\text { a hard time } \\
\text { providing the } \\
\text { desired needs of the } \\
\text { students due to } \\
\text { factors that affect } \\
\text { the student's level } \\
\text { of learning and } \\
\text { competencies, and } \\
\text { because of } \\
\text { overlapping } \\
\text { activities ( } \\
\text { submission of } \\
\text { required papers, } \\
\text { seminars, trainings } \\
\text { and meetings). }\end{array}$ & $\begin{array}{l}\text { *Teachers } \\
\text { encountered and } \\
\text { taught children } \\
\text { with different } \\
\text { learning abilities } \\
\text { and difficulties, } \\
\text { with different } \\
\text { norms and living } \\
\text { condition. } \\
\text { *Teachers deal with } \\
\text { these by } \\
\text { committing } \\
\text { demonstrating } \\
\text { sensitivity to each } \\
\text { student's } \\
\text { uniqueness and by } \\
\text { using positive } \\
\text { discipline. } \\
\text { Keeping a checklist } \\
\text { to follow how } \\
\text { students' are } \\
\text { spending time } \\
\text { during school hours } \\
\text { and the activities } \\
\text { that have the most } \\
\text { time. }\end{array}$ & $\begin{array}{l}\text { *Encouraging each } \\
\text { student to explore } \\
\text { ask questions, show } \\
\text { inquisitiveness to } \\
\text { learn something } \\
\text { new, and learn by } \\
\text { doing and through } \\
\text { playing }\end{array}$ & $\begin{array}{l}\text { *Teachers are proud } \\
\text { being a multigrade } \\
\text { teacher. }\end{array}$ & $\begin{array}{l}\text { * Placing children } \\
\text { at the center of the } \\
\text { attention by giving } \\
\text { rewards ( } \\
\text { additional } \\
\text { points/stars, gifts, } \\
\text { snacks, supplies, } \\
\text { etc) helping them } \\
\text { progress through } \\
\text { their own stages of } \\
\text { learning at their } \\
\text { own pace and } \\
\text { speed. }\end{array}$ \\
\hline
\end{tabular}

There are two basic types of groups according to Johnson (2016) heterogeneous and homogeneous groups. In a heterogeneous group there are a wide range of abilities. In a homogeneous group the students have similar interests and abilities. These are sometimes called cluster groups. A teacher must decide which type of group would be best for the activity. Cluster grouping works great for talented and gifted students so that they can speed ahead and learn at their ability level. However, heterogeneous ability grouping teaches students how to work together with people with different strengths to complete a task. Moreover, planning groups for a heterogeneous or homogeneous group account personalities as well as ability levels should be observed. In addition, it is very important that each person has a role or job in the lesson or project. Selecting a leader for each group also helps students to stay on task. Always remember that whole-group instruction and seatwork aren't always the order of the day. When it's time to form small groups, keep the options fluid and flexible. Students will welcome the many opportunities to work with different classmates in different ways

\section{$M G$ education does not entirely assure a good quality education. Teachers are having a hard time providing the desired needs of the students due to factors that affect the student's level of learning and competencies, and because of overlapping activities (submission of required papers, seminars, trainings and meetings).}

Question arises regarding the quality of multigrade education. Though some researches outside Philippines stated that multigrade teaching are having advantages to the learners but we cannot deny the fact that serving or 
teaching two or more grade levels simultaneously is very hard.

Not that exactly. There are competencies left behind. Some of them were not taught clearly and effectively. AT the end of the day, you cannot serve two masters at the same time with quality services. You have to prioritize one thing. That is why in multi grade class, quality is 50-50 at stake for me

Some multigrade teachers in the Division of Southern Leyte perceived multigrade education is not entirely assuring a good quality education. The fact that teachers are always having difficulties in planning because of the scarcity of structured programs for it same as with the usage of instructional materials and resources for an effective learning outcomes. It compromises the quality of education that the learners have to acquire. Moreover, there is a difficulty in managing the students' misbehavior mostly in a composite class of three or more grade levels where students possess exemplary diverse attitudes and learning. Multigrade teachers do their best for quality education is concerned even though they are having a hard time planning their lesson teaching their students, look and consider the competencies which as much as possible will not left behind. In addition, multigrade teachers also do other related activity in school such as making reports that are urgent and sending themselves to seminars not with the context of multi-grade education but of other context. These travails of multigrade teachers somehow affect the teaching and learning process in providing quality education to the learners.

Teachers encountered and taught children with different learning abilities and difficulties, with different norms and living condition. Teachers deal with these by $c$ demonstrating sensitivity to each student's uniqueness and by using positive discipline.

Multigrade Teachers teaching a heterogeneous class is embedded with utmost desires to impart learning despite the diversity possess by the learners. Children with different learning abilities should be taught accordingly with their needs. According to Chapman and King (2003), a mixed-ability classroom consists of a group of students with differing levels of learning abilities, interest, and skills. Hedge (2000) noted that teaching a classroom of mixed-ability students is a vital and genuine issue that instructors experienced daily. He also went on to reckon that the mixed-ability problem demanded serious attention from experts in the educational field. Learners with various capacities are those that have a broad range of preferences and learning styles. They can also be referred to as a variation of students in their abilities in grammatical knowledge, fluency and accuracy, size of vocabulary, receptive and productive skills (Valentic, 2005).

There are many factors which may differ from one student to another such as their motivation, attitude, and self-discipline (Lightbown \& Spada, 2006). Multigrade teachers find it difficult to effectively plan for their lessons to ensure that all their students reap the required benefits from the lesson.

I encountered and taught children with different learning abilities and difficulties especially when learning abilities interfere with basic skills, such as reading, writing, or math

This is especially a challenge for the multigrade teachers who are not so much equipped with the required skills and teaching methods to deal with mixed-ability classes (Ansari, 2013). Most multigrade teachers have sorted to address this problem by dividing the classes according to their ages. But these classes are still multileveled since these are still deemed random when individual abilities are considered. Studies have shown that random grouping does not incorporate the level of ability and attainment skills of individual students. Putting as many ways of learning into a lesson as multigrade teachers can and when teaching kids will have to their part by taking down notes, do some paragraphing such as reading the paragraph, use of mock ups and manipulative materials or even exposing them to computer aided instructions and transfer theories to experience by having multigrade teachers demonstrate sensitivity to each learners' capacity in putting knowledge into practice by themselves.

In addition, teachers may put four or five different learning styles considering the uniqueness of each 
Quality at stake: Travails of the multigrade teachers in the Division of Southern Leyte

learners and their learning style to show positive discipline into one lesson so that the student who learns best by reading is not left out. Neither way around that student has who learned best by moving around. These various facts challenges to the teachers who try to give equal opportunities for learning to all the students in the class (Boaler, 2013).

Keeping a checklist to follow how students are spending time during school hours and the activities that students frequently do

Checklists are assessment tools that set out specific criteria, which educators and students may use to gauge skill development or progress. Checklists may be used with students for every subject. Checklists set out skills, attitudes, strategies, and behaviors for evaluation and offer ways to systematically organize information about a student or group of students (Lauzon, 2014). Multigrade Teachers have always watched and observed students in the classroom and they have made instructional decisions based on these observations. Observations can take place in a variety of settings. They can focus on student performance during a single activity or during routine classroom activities. Having a checklist of observations of learners will help teachers trace easily how students behave in the class. Multigrade teachers use checklist such as anecdotal records which is common to every multigrade teachers. Anecdotal notes are used to record specific observations of individual student behaviors, skills and attitudes as they relate to the outcomes in the program of studies. Such notes provide cumulative information on student learning and direction for further instruction (Alberta, 2018).

Checklists are assessment tools that set out specific criteria, which educators and students may use to gauge skill development or progress. Checklists may be used with students for every subject to set out skills, attitudes, strategies, and behaviors for evaluation and offer ways to systematically organize information about a student or group of students (Lauzon, 2014). Multigrade Teachers have always watched and observed students in the classroom and they have made instructional decisions based on these observations. Observations can take place in a variety of settings. They can focus on student performance during a single activity or during routine classroom activities.

Encouraging each student to explore, ask questions, show inquisitiveness to learn something new, and learn by doing and through playing.

In every teaching-learning process, students always seek for attention to be given by their teachers. So in multigrade classroom, teachers always ask questions to the students who frequently misbehave in the class and give appropriate actions to their needs. In imparting the lesson, teacher should always ask HOTS questions in order to develop their reasoning ability. HOTS is a creative program designed to build the thinking skills of educationally disadvantaged students The HOTS learning activities involve tasks that are complex but fun, and students' success at these tasks leads to their realization that thinking and persevering can accomplish the seemingly impossible. Valdez (2017) showed simultaneous improvement by HOTS students in six categories: basic skills, writing skills, metacognition skills, grade point average, key Intellectual Quotient components, and ability to solve new problems. The HOTS students outperformed a comparison group of students in each of these areas, even though the comparison students spent more time in the classroom.

In nowadays current trend of education which promotes learner-centered teaching process, students have their time to learn the things by not only listening to theories but to expose them and let them do it on their own. Dewey's theory of learning by doing promotes radical change in school façade. Letting the students used the tool for getting results which openly viewed as learning should be relevant rather than only theoretical. This theoretical approach is helpful to the multigrade class because while teaching other class, the teacher will let the other group to do such task provided by instructions. By that, the teacher provides learners a learning opportunity wherein they are able to discover the things they need by discovering it themselves than acquiring it through simple discussion.

For an instance, in Mathematics subject where the lesson is about finding the perimeter of the object, a 
multigrade teacher can simply group the learners and ask one to measure the length and width of the classroom while the other one measure the length and width of the stadium or their plaza inside the school. While the group of learners is doing the task, the multigrade teacher performs a discussion with other combined grade level with other topics. Then after, the teacher will give other sets of activities to the combined groups pertaining to what has been discussed while generalizing the outputs of the other group emphasizing that learning Math is not always difficult but also engaging one. Teachers should ensure that students get the idea of measuring parameters with concrete and feasible things rather than drawings posted or drawn in the chalkboards. By that, learning is maximized to the extent of exploring the lessons, learning something new and most importantly, learning by doing. In addition, the strategic, active engagement of students in opportunities to learn through doing, and reflection on those activities, which empowers them to apply their theoretical knowledge to practical endeavors in a multitude of settings inside and outside of the classroom (Hakathurna et al., 2011).

Teachers are proud being a multigrade teacher - Multigrade teachers in the Division of Southern Leyte feel proud of being one because it is not an easy job but still they manage the whole thing and survive their struggles. In most cases, they let their students compete with the students from the monograde class and fortunately win the competition. It makes them feel proud because despite situations and shortcomings in promoting quality education, they still manage to put up a good fight.

Oo ui kay bisan ug multigrade mi mapakita namo nga naningkamot mingtudlo pinaagi sa among mga bata nga mu-apil ug mga district contests. Ang uban makadaug ang uban di kay lagi kuwang kaajo ang panahon sa pagmentor ug pag coach"

Yes, despite the fact that we are multigrade teachers, we can show that we are trying our best in teaching by letting our learners join district contests. Some wins but some losses due to lack of time to teach

With all the scarcity and shortage in terms of learning materials and even poor school facilities, multigrade teachers manage their students to excel in the field of sports and academic competitions wherein they were able to represent the division to the regional levels. That would mean that even they came from multigrade school but still they can compete to the Monograde School or even surpasses them.

Placing children at the center of the attention by giving rewards (additional points/stars, gifts, snacks, supplies, etc.) helping them progress through their own stages of learning at their own pace and speed.

In most multigrade schools in the Division of Southern Leyte are located in remote areas or small communities which have low population density and has low income because probably of the location that affects the livelihood of the people in the community. Most learners in multigrade schools are not only deprived from learning materials and resources from the government but also they experience scarcity of foods. They have limited supply of foods mostly if their parent's job is farming, fishing or even contractual unskilled job. This may result to poor income of the family which may cause the scarcity of good and delicious food as intake of the learners.

Research has shown that students are able to learn better when they're well nourished, and eating healthy meals has been linked to higher grades, better memory and alertness, and faster information processing. Furthermore, recent studies have demonstrated that nutrition affects students' thinking skills, behavior, and health, all factors that impact academic performance. Research suggests that diets high in trans and saturated fats can negatively impact learning and memory, nutritional deficiencies early in life can affect the cognitive development of school-aged children, and access to nutrition improves students' cognition, concentration, and energy levels (Bellisle, 2004). 
Quality at stake: Travails of the multigrade teachers in the Division of Southern Leyte

So mostly multigrade teachers are expecting the scenario mentioned above and since the students are the center of the teaching-learning process, the lesson will be affected if learners are not participative due to hunger. To depreciate the unfortunate situation of the students, the multigrade teachers offer rewards to the students who will perform well or behave well in the class in the means of foods, snacks, chocolates and candies. Some learners in multigrade classroom don't have the chance to eat candies and chocolates most especially to those who lived in a mountainous place.

"I offer rewards for my students and provide them options such as I will give them additional scores or I will give them chocolates and candies. I am expecting that they will choose additional scores but to my surprise, they have chosen the chocolates and candies for the simple reason that they haven't tried or eaten those although the years. So from then on, I will give them rewards for them to be motivated to learn and participate by foods, chocolates and candies".

An effective behavior modification system within the classroom always often includes rewards. Students are motivated to achieve and conform to appropriate behaviors when either intrinsically or extrinsically rewarded. Those students who prefer intrinsic motivation enjoy praise, personally challenging projects and accomplishing educational tasks just for the love of learning. An extrinsic approach requires more tangible rewards such as pencils, erasers, stickers and sometimes candy. The type of reward given to students must be fair and consistent for all students but also must vary for each task (Gerdin, 2016).

Rewarding students encourages and endorses school effort. They lead to improved outcomes for students. Moreover, multigrade teachers are always plausible with choices and rewards given to children in the classroom (Khon, 1994) will lead to more learning instead of just remembering. Teachers adapt this intervention even if they caused them an amount of money because of their willingness to help young learners. They believed that when these are a regular part of school structure, children work harder and longer on tasks, and will seek out more creative solutions to problems (Adelman, 1989; Amabile \& Gitomer, 1984; Maehr \& Stallings, 1972) as cited by Kohn (2013).

\subsection{Character}

In most profession, teaching seems to be a noble one for it requires a vast and maximum effort to educate young and empty minds. Thus, positive views and optimistic traits must have in a teaching career. The love of teaching is a concrete justification of the principle in education that says, "Teach to live and not live to teach". The courage of the multigrade teachers in teaching two or more grade level in a day with the prescribed curriculum. It will give the idea on how they characterize themselves to cater all the needs of the learners and to the stakeholders' expectations. The table below shows the travails of the multigrade teachers as to how they characterize themselves in the teaching-learning process. Teachers have difficulty in balancing time and multi-tasking. They exert more effort as facilitators, planners, material designers, researchers, counselors, surrogate parents and as community liaison to ensure efficiency in time and be more effective as a teacher. Teachers have difficulty in getting through risky and remote locations, lacking of tools and resources for the school. Teachers form strategies on how to spend time and money to supply their needs. To have the courage, patience and being positive in facing difficult situations. An Mg Teacher is patient, compassionate, committed and optimistic to the learners. Quality education depends on teachers' skills and attitude towards challenges and opportunities of the student and other factors. 


\section{Teachers' view in terms of character on Multigrade Education}

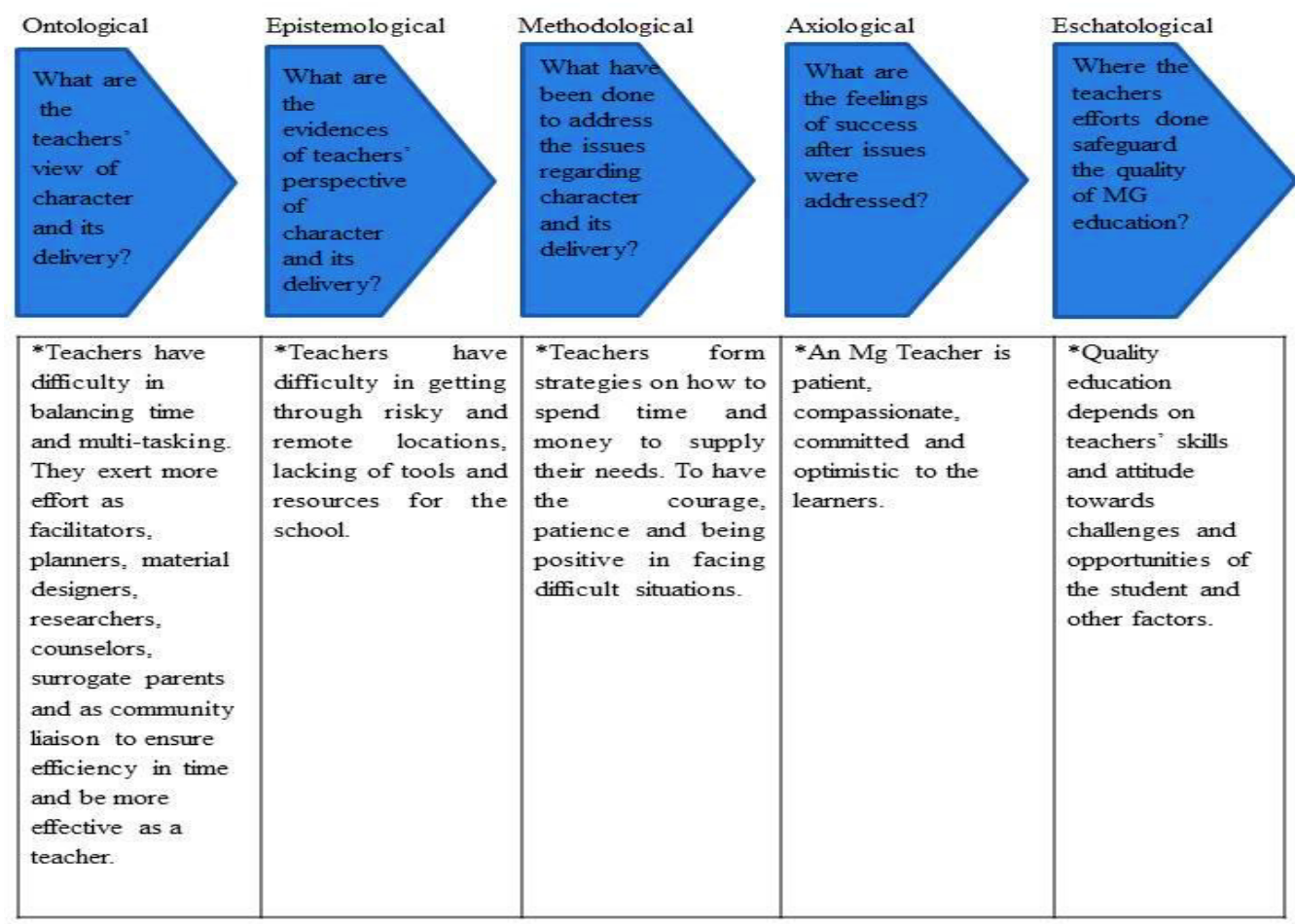

Teachers have difficulty in balancing time and multi-tasking. They exert more effort as facilitators, planners, material designers, researchers, counselors, surrogate parents and as community liaison to ensure efficiency in time and be more effective as a teacher.

With the above mentioned statements on how multigrade teachers balance their time and do a lot of multitasking, their job does not end there. They don't feel comfortable preparing for two or more grades, so they develop different programs for the different grades. Trying to do this is very difficult to plan and manage. It would be impossible to cover all the work for each grade if the teachers will not do multi-tasking. Since multitasking is to deal with more than one task at the same time (Webster, 2014) for multigrade teachers it views them as a normal phenomenon in their profession.

Moreover, in the classroom they were facilitators to different grade levels combined as one to facilitate learning in their maximum capacity. Facilitators might not be subject area experts like a teacher. They do have special training in group dynamics, using processes such as conflict resolution, strategic planning and team building. In any group setting, a facilitator can quickly determine what the group knows so the group can proceed to build on that knowledge. By asking questions and keeping the group focused, a facilitator helps the group establish a set of ground rules, as well as its own learning objectives. The facilitator also helps the group evaluate what group members learned from their activities (Mariano \& Kirby, 2009).

Multigrade teachers do a lot of planning because it is widely known that there is scarcity of appropriate programs for multigrade classes. In the Division of Southern Leyte, to adhere with the competencies of promoting quality education, teachers do a lot of planning of what is suited to the learners needs and to cater their abilities. They plan of what to do, what to prepare, how to do and what is need to be done. Seemingly, the efforts of the creation of instructional materials where learners' materials are also lacking. With the help of outside sources such as internet and other books, teachers are considered as researchers because they outsourcing and select or choose what materials to be made considering how it will create resounding outputs from the learners. If a monograde teacher prepares variety of materials for his/her variety of learning individual in one grade only monograde students how much more a multigrade teachers prepares varied materials considering the 
varied abilities and learning styles in two or three grade classes.

The job of the multigrade teacher is not only being a planner, designer and a researcher. Most of the time in the classroom situation, they are counselor for their learners disputes and misunderstanding. Teachers cannot deny the occurrence of fight in the classroom especially if handling three or more grade levels simultaneously. The teacher will have to stop the discussion just to settle the students misunderstanding. Then being a parent or a surrogate parenting comes in mostly if the fighting is all about bullying of not having a complete family. The surrogacy of the parent was talking about is not the scientifically way but on how the teacher embraces and fill in the necessity of the child having a mother or a father figure when the environment around them made them feel unsecured. It made them even a good community liaison wherein they have the opportunity to discuss to the class how important respect to one another.

Teachers have difficulty in getting through risky and remote locations, lacking of tools and resources for the school.

Multigrade teaching in many views represents a more demanding teaching situation and special attention should be given to it. Frequently multi-grade teaching is required not by choice but through force of circumstances. The multi-grade class may be a reflection of extreme socio-economic constraints, or a small population (as in the case) in the surrounding community.

The characters of the multigrade teachers especially to those who are assigned in the remote areas are extraordinary because they are facing double struggles because of the geographical location of the school. They know that their life is at risk with the remote locations and rough roads they need to travel. The risk of having greater chances of vehicular accidents when school is accessible with "habal-habal" or a motorcycle designed for mountainous places. Likewise, with the risk encountered by the multigrade teachers who walk barefoot to their stations.

\footnotetext{
Hazardous road; risky in crossing river/s; not enough materials for teaching; financial problem; low retention of the learners; time management during discussion in 2 grades; I deal with this difficulties by initiative for materials that needed; search some strategies for teaching and embracing all the risky travels but $n$ choice.
}

Mostly risks are having injuries if they fall into muddy road or being bitten by the venomous snakes. There hardships will not be complete without spending money for the fare of the "habal-habal". In addition, mostly teachers assigned in far-flung areas bring with them groceries that will last them for weeks. Though they can save money for that, but it risks their health because of too many preservatives in canned goods and noodles.
I need to prepare lessons ahead of time because handling four grades (kinder to grade 3) is not an easy job. Various materials taken from the lessons are necessary to address their needs. Coping also with their behaviors in learning for most of the time I spent my class teaching values so that learners will behave accordingly. Browsing the internet to help my burden in finding alternative way in teaching my students

Most schools with multi-grade classes do not have the adequate resources they need to hire additional teachers, or build additional classrooms. They lack essential support personnel, such as janitors or administrative staff, and are unable to buy materials or equipment, such as overhead projectors, computers or photocopying machines. Multi-grade classes may also be the result of the geographical, socio-economic or cultural conditions of the community or neighborhood.

Teachers form strategies on how to spend time and money to supply their needs. To have the courage, patience and being positive in facing difficult situations.

Teacher in a multigrade classroom needs to have varied stratgeies and activities for them to be more applausive 
by their learners. Many of them used experiential learning so that students can grasp the first hand information in discovering it by themselves.

Learning by doing is one method or strategies that I applied where students learn much. They feel that they are part of the class discussion since they are the one who work for it through concrete objects. The experiential learning makes the learners busy and behave upon focusing doing the activity. By that, I can easily manage them and my time to teach other grade levels simultaneously

In terms of the financial needs of the multigrade teachers in making their activities more enjoyable and captivating, they link on outside sources and linkages such as PTA or private individual to donate or give their generosity for the materials; hence most of their salary is spent in providing their students.

\begin{abstract}
A good MG Teacher is a good facilitator and resourceful. Resourceful in terms of linking outside sources to finance our materials. Like for example, during brigade eskwela where NGOs, PTA and private individuals are working hand in hand in making the school and classroom beautiful more conducive to learning. By then, we teachers knock their benevolent heart to donate any materials for the teaching-learning process".
\end{abstract}

An Mg Teacher is patient, compassionate, committed and optimistic to the learners

Quality education depends on teachers' skills and attitude towards challenges and opportunities of the student and other factors.

Dealing with the difficulties, the multigrade teacher remains patient, compassionate, committed and optimistic to the learners despite the actual fact that they mostly lose their temper if students misbehaved in the class. They are always patients in handling the class though learners lack values mostly to the younger learners. Multigrade teachers exerted a lot of it when instances like class interruptions and mostly if the learners have low learning capacity where they have to reteach and reteach and reteach considering or trying to use different approaches just to ensure that learners learned in their own levels and ways of understanding. Compassion is described as the disposition of accepting and caring for others, particularly as treating them with kindness and concern in adversity (Neff,2003). Multigrade teachers need to be compassionate because they need to love their students for them not to get exhausted. Teachers treat their learners as their own children so that they instill discipline out of love.

Commitment comes along if you are compassionate with your job. Multigrade teachers commit themselves though they face a lot of struggles in teaching quality education. Amidst adversities and hectic schedules and reports submission, they find time to at least work it out by having them the commitment with themselves that even they wanted to give up on things especially on students who are not cooperative and who are learning at all. They always seek for an alternative way to cater and help those learners because they are optimistic and don't want learners left behind. They are optimistic by proving or telling the students the moral support so that learners would feel that they are taken care of and they are never abandoned.

Though multigrade teachers assigned in far-flung areas received an annual hardship allowance depending on how far their station is or how many classes they have but it cannot compensate with the obstacles they are facing every day. Quality education depends on teachers' skills and attitude towards challenges and opportunities of the student and other factors.

Teaching and administrating activities in my class without my learners having enough materials with them like ball pen or paper/notebook. Dealing with this by providing them. Every payday I reserved $10 \%$ of my salary for school supplies

A skillful multigrade teacher carry on the challenges and burden of those students who were unfortunate to have

116 Consortia Academia Publishing (A partner of Network of Professional Researchers and Educators) 
a complete set of school supplies due to poverty by providing them their basic needs and imparting their salary or personal money. Many teachers believe that providing their students in any kind will help their students perform better in the class.

I produce DLL, study it and construct IM's. Making sure that my learners will get the necessary lessons. In imparting, following the flow of the DLL is a must but observation and enhancement of the process took place after. The difficulty I always encountered was the lack of learning resources.

Pursuant to the DepEd Order No. 42 S. 2014 also known as the Policy Guidelines on Daily Lesson Preparation for the K to 12 Basic Education Program the teachers have to follow strictly the format of the daily lesson log both monograde and multigrade. It will help the teachers organize their lessons and preparations.

I just only follow the Teacher's Manual given and so some adjustments by not using the learning content if it no "friendly" of favor for my learners' capacity. I find it difficult in preparing the necessary instructional materials and learning resources specially to subjects that there's no learner's guide available. In actual teaching, the difficulties I encountered is the implementation of differentiated instruction because it because a lot of time, I need more teaching strategies to enhance better my teaching skills especially in actual teaching.

One of the challenges of a multigrade teacher is to equate the lesson to the learners' need considering their different attitudes and learning styles. Teaching strategies plays vital in teaching but teachers find so hard of what are those strategies best suited hence strategies needed to be well-crafted, well-adjusted and well-implemented upon the adherence of quality education.

\section{Summary of findings}

The multigrade teachers gave their best effort to deliver quality multigrade education; the teachers always find time and manage it in crafting their lessons parallel to the content prescribed by the curriculum guides, teacher's guides and learning materials by the Department of Education. They maximize different approaches to learning and as much as possible link-up classroom or school learning with daily life. In this way, children will really learn how to learn. Also teachers always trying to make connections with their learners grouped in different levels and ages ensure to cater all their individual needs in the simplest ways so that students can easily grasp the knowledge and skills taught and provided by the multigrade teachers. Connecting students' experiences as well as their interest to the lessons that can be associated by all means whichever effective or not. And the multigrade teachers ethically and professionally conducted their character in handling children with different diverse background and needs. Teachers put lot of efforts in having extra miles of courage, strength, motivation, patience, resourcefulness, creative, innovative, industry and perseverance for their learners. They have to behold pleasing character and dignifies at all times in all places as they considered themselves a model to their learners. They believe that teachers are instrument for strong foundations of quality education.

\subsection{Conclusion}

In general, the travails of the multigrade teachers always fall into enhancing and crafting the content of prescribed curriculum due to lack of ready-made appropriate materials and lesson plans to easily connect to the learners needs and different learning styles. Seemingly with their character which will always be very flexible so that they can easily adjust to the arising difficulties and inconsistency of the teaching-learning process towards quality of the multigrade education.

\subsection{Recommendations}

Based from the findings of the study, it is hereby recommended to: 
$>\quad$ Use a number of planning strategies and demonstrate a range of teaching strategies used in multigrade classroom;

$>\quad$ Choose appropriate assessment tasks for the multigrade classroom;

$>\quad$ Design the quality of seminars to approaches that are appropriate to multigrade education;

$>$ Develop units of work based around accurate approach, incorporating objectives found in the curriculum guides, Teaching guides and Learners materials for better quality education.

\subsection{Output Description}

With the help of this study, the researcher had the chance to create an output featuring the three C's (Content, Connection, and Character) to explore, narrate and document the travails of multigrade teachers to better understand their responsibilities in providing quality to the multigrade education.

\section{References}

Adelman, H. S. (1989). Opinion papers: Toward solving the problems of misidentification and limited intervention efficacy. Journal of Learning Disabilities, 22(10), 608-612.

Alberta, H. (2018). Classroom assessment scoring system-secondary: Reliability and validity study in Alberta, Canada.

Allen, S. (2004). Designs for learning: Studying science museum exhibits that do more than entertain. Science Education, 88(S1), S17-S33.

Alrajhi, M. N., et al. (2015). Peer tutoring effects on Oman student's English self-concept. Peer Tutoring.

Amabile, T. M. (1985). Motivation and creativity: Effects of motivational orientation on creative writers. Journal of personality and social psychology, 48(2), 393.

Amzat, I. H., \& Valdez, N. P. (Eds.). (2017). Teacher empowerment toward professional development and practices: Perspectives across borders. Springer.

Ansari, M. S. (2013). Coping with the problems of mixed ability classes: A study in the context of teaching English as SL/FL. International Journal of English: Literature, Language \& Skills, 10, 182.

Aryal, P. N., Neupane, S. R., Laudari, D. C., \& Bhattarai, K. R. (2003). A study on multigrade/multi-class teaching: status and issues. Formative Research Project.

ASCD. (2018). Education resource. Whole child for the whole world: for each child and the common good. http://inservice.ascd.org/whole-child-for-the-whole-world-for-each-child-and-for-the-common-good/

Ball, D. L., Thames, M. H., \& Phelps, G. (2008). Content knowledge for teaching: What makes it special. Journal of teacher education, 59(5), 389-407.

Barett et al. (2006). The concept of quality education: A review of the international literature in the concept of quality education.

Bass, B. M. (1993). Theory of transformational leadership. Being a Good Leader. Retrieved from https://www.sciencedirect.com/science/article/pii/1048984395900217

Beihammer, E. K., \& Hascher, T. (2015). Multi-grade teaching practices in Austrian and Finnish primary schools. International Journal of Educational Research, 74, 104-113.

Bellisle, F. (2004). Effects of diet on behavior and cognition in children. British Journal of Nutrition, 92(2), S227-S232.

Benveniste, L. A., \& McEwan, P. J. (2000). Constraints to implementing educational innovations: The case of multigrade schools. International Review of Education, 46(1-2), 31-48.

Berry, B., Johnson, D., \& Montgomery, D. (2005). The power of teacher leadership. Educational Leadership, 62(5). 56.

Berry, C. (2001). Achievement effects of multigrade and monograde primary schools in the Turks and Caicos Islands. International Journal of Educational Development, 21(6), 561-566. 
Quality at stake: Travails of the multigrade teachers in the Division of Southern Leyte

Berry, C. (2010). Multi-grade teaching. Discussion Document.

Birch, I., \& Lally, M. (1995). Multi-grade teaching in primary schools. Asia- Pacific Centre of Educational Innovation for Development.

Boaler, J. (2013). Mathematics of hope. https://doi.org/10.1080/01411920701532145

Boonzaaier, P. J. V. (2008). Multi-grade rural schools' intervention in the West Coast, Wine lands EMDC: A case study [Education thesis]. University of Technology, Wellington, South Africa.

Brown, K. D. (2014). Teaching in color: A critical race theory in education analysis of the literature on preservice teachers of color and teacher education in the US. Race Ethnicity and Education, 17(3), 326-345.

Buchert, L. (1995). The concept of education for all: What has happened after Jomtien? International Review of Education, 41(6), 537-549.

Burns-Glover, A. L., \& Veith, D. J. (1995). Revisiting gender and teaching evaluations: Sex still makes a difference. Journal of Social Behavior and Personality, 10(4), 69.

Castillo, C. C., Tanaka, K., Sato, Y. I., Ishikawa, R., Bellina, B., Higham, C., ... \& Fuller, D. Q. (2016). Archaeogenetic study of prehistoric rice remains from Thailand and India: Evidence of early japonica in South and Southeast Asia. Archaeological and Anthropological Sciences, 8(3), 523-543.

Chandra, G. (2004). Zambia's multigrade experience. Ministry of Education.

Chapman, C., \& King, R. (2003). Differentiated instructional strategies for reading in the content areas. Thousand Oaks, CA: Corwin Press.

Chickering, A. W., \& Gamson, Z. F. (1987). Seven principles for good practice in undergraduate education. AAHE bulletin, $3,7$.

Chickering, A. W., \& Gamson, Z. F. (1999). Development and adaptations of the seven principles for good practice in undergraduate education. New directions for teaching and learning, 80, 75-81.

Coetzee, D., et al, (2015). Structuring interactions for large scale synchronous peer learning. Retrieved form http://www.eecs.bekerley.edu

Corbin, J. M., \& Strauss, A. (1990). Grounded theory research: Procedures, canons, and evaluative criteria. Qualitative sociology, 13(1), 3-21.

Cox, J. (n.d.). Teach hub.com. Retrieved http://www.teachhub.com/flexible-grouping-differentiated-instruction-strategy

Cox. (3018). International teaching methods. Retrieved http://www.ea.gr/ep/nemed/fls/95589507826368International_Teaching_methods_summary.doc.

Craft, A., Horin, O. B., Sotiriou, M., Stergiopoulos, P., Sotiriou, S., Hennessy, S., ... \& Dobrivoje, E. L. (2016). CREAT-IT: Implementing creative strategies into science teaching. In New developments in science and technology education (pp. 163-179). Springer, Cham.

Dalli, C. (2008). Pedagogy, knowledge and collaboration: towards a ground-up perspective on professionalism. European Early Childhood Education Research Journal, 16(2), 171-185.

Darmer, M. A. (1995). Developing transfer and metacognition in educationally disadvantaged students: effects of the Higher Order Thinking Skills (HOTS) program [Unpublished dissertation]. University of Arizona.

Dodendorf, D. M. (1983). A unique rural school environment. Psychology in the Schools, 20(1), 99-104.

Dupriez, V., Dumay, X., \& Vause, A. (2008). How do school systems manage pupils' heterogeneity? Comparative Education Review, 52(2), 245-273.

Dzulkifli, M. A., \& Mustafar, M. F. (2013). The influence of color on memory performance: A review. The Malaysian journal of medical sciences: MJMS, 20(2), 3.

Ellias, O. (2011). Options for youth: The importance for eating health for students. Retrieved https://ofy.org/blog/the-importance-of-eating-healthy-for-students/

Enayati, et al. (2016). Classroom management strategies of multigrade schools with emphasis on the role of technology. Research article.

Gaustad, G., Olivetti, E., \& Kirchain, R. (2010). Design for recycling: Evaluation and efficient alloy modification. Journal of Industrial Ecology, 14(2), 286-308.

Gawe, et al. (2011). Multi-grade teaching and quality of education in South African rural areas.

Gerdabi. (2013). Multigrade in social interactions. Retrieved from http://journal.frontierism.org 
Gerdin, R. (2016). An intrinsic and an extrinsic approach to reading enclave.

Grant, E. H. C., Nichols, J. D., Lowe, W. H., \& Fagan, W. F. (2010). Use of multiple dispersal pathways facilitates amphibian persistence in stream networks. Proceedings of the National Academy of Sciences, 107(15), 6936-6940.

Green, K. B., Terry, N. P., \& Gallagher, P. A. (2014). Progress in language and literacy skills among children with disabilities in inclusive early reading first classrooms. Topics in Early Childhood Special Education, 33(4), 249-259.

Gudmundsdottir, S., \& Shulman, L. (1987). Pedagogical content knowledge in social studies. Scandinavian Journal of Educational Research, 31(2), 59-70.

Gunert. (1997). Retrieved from https://teachingcommons.stanford.edu/resources/learning-resources/promoting-active-learning

Hargreaves, E., Montero, C., Chau, N., Sibli, M., \& Thanh, T. (2001). Multigrade teaching in Peru, Sri Lanka and Vietnam: an overview. International Journal of Educational Development, 21(6), 499-520.

Hedge, T. (2000). Teaching and learning in the language classroom. Oxford, UK: Oxford University Press.

Hlalele, D. (2014). Creating sustainable rural learning ecologies in South Africa: Realities, lessons and prospects. Journal of Human Ecology, 45(2), 101-110.

Hoffman, J. (2002). Flexible grouping strategies in the multiage classroom. Theory into Practice, 41(1), 47-52.

Hyry-Beihammer, E. K., \& Hascher, T. (2015). Multi-grade teaching practices in Austrian and Finnish primary schools. International Journal of Educational Research, 74, 104-113.

Johnson, D. W., \& Johnson, R. T. (2009). Energizing learning: The instructional power of conflict. Educational Researcher, 38(1), 37-51.

Johnson, L., \& Van Wyk, M. (2016). Approaches to teaching EMS: The teacher-centered approach. Oxford University Press.

Kalaoja, L., \& Cornish, R. (2016). Challenges and disadvantages of multigrade teaching: Qualitative research.

Khon, S. (1994). Scalable parallel numerical methods and software tools for material design.

Kirby, J. R., (2009). Enhancing the quality of learning: Dispositions, instruction, and learning processes. Cambridge University Press.

Kivunja, C., \& Sims, M. (2015). Perceptions of multigrade teaching: A narrative inquiry into the voices of stakeholders in multigrade contexts in rural Zambia. Higher Education Studies, 5(2), 10-20.

Kucita, et al. (2013). Bhutanese stakeholders' perceptions about multi-grade teaching as a strategy for achieving quality universal primary education. International Journal of Educational Development, 22, 206.

Lauzon Clabo, L. M. (2008). An ethnography of pain assessment and the role of social context on two postoperative units. Journal of advanced nursing, 61(5), 531-539.

Lightbown, P. M., \& Margaret, N. S. (2006). How languages are learned, 3, 342.

Lingam, G. (2007). Pedagogical practices: The case of multi-class teaching in Fiji primary school. Educational Research and Review.

Little, A. W. (1995). Multi-grade teaching: A review of research and practice. ODA.

Little, A. W. (2005). Learning and teaching in multigrade settings. Paper prepared for the UNESCO 2005 EFA Monitoring Report. Paris: UNESCO.

Little, A. W. (2007). Education for all. In Little, A.W. (Ed.), Education for all and multigrade teaching: Challenges and opportunities. Dordrecht: Springer.

Little, A. W., Pridmore, P., Bajracharya, H., \& Vithanapathirana, M. (2006). Learning and teaching in multigrade settings (LATIMS). Technical report. Department for International Development (DFID).

Maehr, M. L. (1974). Culture and achievement motivation. American Psychologist, 29(12), 887.

Mariano, G. (2009). Analysis of teacher accommodation recommendations for a large-scale test. Technical Report\# 09-05. Behavioral Research and Teaching.

Matchidiso, J. (2014). Quality basic education for all: Challenges in multi-grade teaching in rural schools. Mediterranean Journal of Social Sciences, 5(1), 531.

Miles, L. D. (2015). Techniques of value analysis. Miles Foundation.

Monbush, G. (1989). A survey of multigrade schools in the Eastern Cape. University of Fort Hare In-service 
Programs. University of Fort Hare.

Nawab, A., \& Baig, S. R. (2011). The possibilities and challenges of multigrade teaching in rural Pakistan. International Journal of Business and Social Science, 2(15), 166.

Neff, K. D. (2003). Self-compassion: an alternative conceptualization of a healthy attitude toward oneself. Self-Identity, 2, 85-101. https://doi.org/10.1080/15298860309032

Ngubane, A. (2012). Perceptions on implementation of quality teaching and learning programs for schooling at Mkhanyakude District.

Patsalides, L. (2012). Bright hub education. Retrieved from https://www.brighthubeducation.com/classroom-management/21256-tips-for-grouping-students-for-gro up-work/

Pied la. (1978). A review of the qualitative research on multigrade instruction.

Pincas, A. (2007). Overview of reported methods of teaching multigrade classes in the developing world.

Pridmore, P. (2001). Multigrade schooling in 'remote' areas of Vietnam. International Journal of Educational Development, 521 - 536.

Pridmore, P. (2004). Education for all: The paradox of multi-grade education. Paper presented at the annual conference of the Council for Education in the Commonwealth, Bangkok, Thailand.

Rudduck, J. (2006). The past, the papers and the project. Educational Review, 58(2), 131- 143.

Seher, C., Buchbinder, D., \& Taylor, K. (2018). Reaching food insecure college students through an on-campus interactive nutrition education program. Journal of the Academy of Nutrition and Dietetics, 118(9), A69.

Shaeffer, S. (2014). Multi-grade pedagogy: Theory, practice and implications for research. PPTs presented at the Regional Research Workshop on Promoting

Smith, J. A. (2008). Qualitative psychology: A practical guide to research methods. London: Sage.

Smith, J. A., Harré, R., \& Van Langenhove, L. (1995). Idiography. In J. A. Smith, R. Harré, \& L. Van Langenhove (Eds.), Rethinking psychology (pp. 56-69). London: Sage.

Smith, R., Hyry-Beihammer, E. K., \& Raggl, A. (2015). Teaching and learning in small, rural schools in four European countries: Introduction and synthesis of mixed/multi-age approaches. International Journal of Educational Research, 74, 97-103.

Stallings, J. (1985). School, classroom, and home influences on women's decisions to enroll in advanced mathematics courses. Women and mathematics: Balancing the equation, 199-223.

Sudhakar. (2018). U.S. Patent No. 10,110,617. Washington, DC: U.S. Patent and Trademark Office.

Taole, M. J. (2014). Multi-grade teaching: A daunting challenge for rural teachers. Studies of Tribes and Tribals, 12(1), 95-102.

Taole, M., \& Mncube, V. S. (2012). Multi-grade teaching and quality of education in South African rural schools: Educators' experiences. Studies of Tribes and Tribals, 10(2), 151-162.

Valentic, D. (2005). ELT in multi-level classes. Hupe Newsletter, 23

Veenman, S. 1995. Cognitive and non-cognitive effects of multigrade and multi-age classes: A best-evidence synthesis. Review of Educational Research, 65(4), 319-381.

Vithanapathirana, M. (2006). Training modules on multigrade teaching for multigrade teachers in Sri Lanka. Colombo: University of Colombo, Faculty of Education.

Welch, A. R. (Ed). (2000). Third world education: Quality and equality. New York, Garland.

Wittaya, K. N. (2013). Challenging education for future change.

Zhu, J. (2014). Quantitative evaluation on professional learning in multigrade. 
Magpatoc, A. G.

122 Consortia Academia Publishing (A partner of Network of Professional Researchers and Educators) 